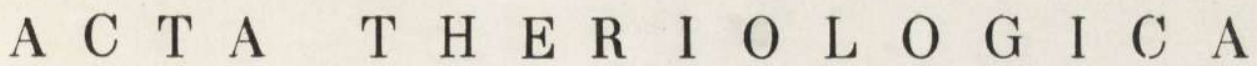 \\ VOL. XII, 38: 533-543. \\ BIAŁOWIEŻA \\ 30.XII.1967
}

Zofia G Ę B C Z Y N S K A

\section{Morphologic Variability of Lagurus lagurus (Pallas, 1773) in Laboratory Conditions}

[With 3 Figs., 5 Tables and Plate XXII]

\begin{abstract}
Body and skull measurements were studied in 281 individuals (136 females and 145 males) of Lagurus lagurus ( $\mathrm{Pa} 11 \mathrm{as}, 1773$ ). The animals were from 1 to 39 months old and were raised in laboratory colony. The results indicate that the length of the body, tail, foot and height of ear as well as all skull measurements (except the interorbital constriction) grow intensively until the animals are 8 months old. Only $\mathrm{Cb}$. and basal lengths continues very slow growth until the end of life. The interorbital constriction attains its definite value in the first month of life. The body weight of $L$. lagurus increases intensively and reaches maximum at the age of approximately 1 year $(17.8 \mathrm{~g})$. Disease of the jaw bones, identified as actinomycosis was frequently observed. This disease attacks the animals already during the first months of life.
\end{abstract}

\section{INTRODUCTION}

A colony of L. lagurus is maintained at the Mammals Research Institute, Polish Academy of Sciences at Białowieża since 1961 (G ę b c z y ń ska, 1967). Our purpose has been to adopt this species to laboratory conditions. The existence of this colony offered an opportunity to study the influence of laboratory breeding on the morphologic indexes of the body and the skull.

The purpose of the present work was to describe the changes of body weight, body measurements, skull measurements and skull external appearance during the post-weaning development of $L$. lagurus raised in laboratory conditions.

\section{MATERIAL AND METHOD}

The skulls to be measured were fixed in alcohol. The precise age of the animals was know from the breeding record. Body measurements: the head and body length, the tail, the hind foot and ear height and body weight were recorded on individual cards. The following dimensions of the skull were measured with a vernier calipes to the nearest $0.1 \mathrm{~mm}$ : condylobasal length, basal length, height of skull per bullae tympanici, depth of the brain case per basi sphenoidale, breadth of the brain case, zygomatic breadth, interorbital constriction, constriction between the zygomatic processes of the temporal bones, palatal depth. 
The significance of differences between individual measurements was computed using the Students $t$-test for two independent groups and Tuckey's test.

Two hundred and eighty one individuals were studied including 136 females and 145 males. The studied individuals were from 1 to 39 months old, counting

Table 1.

alysis of the total material of Lagurus lagurus examined with respect to age.

\begin{tabular}{|c|c|c|c|c|c|c|c|}
\hline \multirow{2}{*}{ Sex } & \multicolumn{6}{|c|}{ Age in months } & N \\
\cline { 2 - 7 } & $1-6$ & $7-12$ & $13-18$ & $19-24$ & $25-29$ & $30-39$ & \\
\hline $0 \%$ & 56 & 44 & 16 & 8 & 11 & 1 & 136 \\
\hline$O^{\circ} O^{+}$ & 68 & 40 & 14 & 13 & 8 & 2 & 145 \\
\hline$N$ & 124 & 84 & 30 & 21 & 19 & 3 & 281 \\
\hline
\end{tabular}

from the date of birth (Table 1). The majority of the animals including all the older ones died a natural death while 1 and 2 months old animals were killed.

\section{RESULTS}

\section{Body weight and body measurements}

Body weight changes considerably during the animals life. The mean body weight of one month old animals was $10.32 \mathrm{~g}$. Later it was increasing; reached a maximum of $17.8 \mathrm{~g}$ at the age of approximately one year and remained relatively stable for the rest of the animals life. Some animals in our colony were much heavier, even over $33 \mathrm{~g}$, but these were only rare exceptions.

In all age groups there were no statistically significant differences between the body weight of males and females. Pregnant females were excluded from these calculations.

The head and body length of $L$. lagurus was increasing intensively until the 8th month of life. In one month old animals the mean head and body length was $72.8 \mathrm{~mm}$ while in 8 months old animals it was $90.6 \mathrm{~mm}$. This represents an increase of $24.4 \%$ (Fig. 1). Older animals were slightly longer but the differences were not significant.

The $t a i l$ length, height of $e a r$ and $h$ ind $f o o t$ length were also increasing until the animals were 8 months old. The body dimensions of the oldest animals (25-39 months) were not significantly different (Fig. 1). The observed range of these dimensions in different age groups was quite considerable (Table 2).

There were no sex differences in any of the studied body dimensions and therefore data on males and females were pooled for presentation in tables and diagrams. 


\section{Skull dimensions}

Condylobasal length was increasing intensively for 8 months. The mean $\mathrm{Cb}$. length at 1 month of age was $19.53 \mathrm{~mm}$ and at 8 months of age is reached $22.22 \mathrm{~mm}$. Considering the former value as

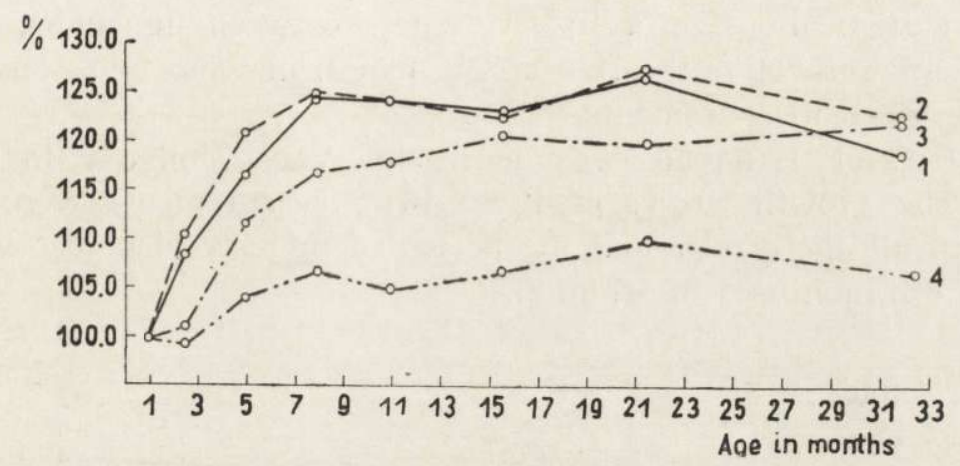

Fig. 1. Per cent increase of body measurements in $L$. lagurus from the laboratory. 1 - Head and body, 2 - Tail, 3 - Height of ear, 4 - Hind foot.

Table 2.

Extremal values means and standard deviations of body measurements in Lagurus lagurus of different age.

\begin{tabular}{|c|c|c|c|c|c|c|}
\hline \multicolumn{2}{|c|}{ Age (months) } & $1-6$ & $7-12$ & $13-18$ & $19-24$ & $25-39$ \\
\hline 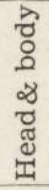 & $\begin{array}{l}\min \\
\max \\
\bar{x} \\
\frac{ \pm}{n} \mathrm{SD}\end{array}$ & $\begin{array}{r}57.5 \\
105.5 \\
82.3 \\
8.6 \\
116\end{array}$ & $\begin{array}{r}77.5 \\
102.5 \\
90.5 \\
6.1 \\
81\end{array}$ & $\begin{array}{r}72.5 \\
107.5 \\
90.0 \\
7.7 \\
30\end{array}$ & $\begin{array}{r}77.5 \\
102.5 \\
92.0 \\
7.7 \\
21\end{array}$ & $\begin{array}{c}72.5 \\
97.5 \\
86.3 \\
7.1 \\
21\end{array}$ \\
\hline$\stackrel{\bar{\pi}}{\tilde{H}}$ & $\begin{array}{l}\min \\
\max \\
\bar{x} \\
\pm \\
\pm\end{array}$ & $\begin{array}{r}7.4 \\
14.4 \\
10.6 \\
1.9 \\
116\end{array}$ & $\begin{array}{r}8.2 \\
14.8 \\
11.3 \\
0.7 \\
82\end{array}$ & $\begin{array}{r}8.8 \\
14.6 \\
11.2 \\
1.7 \\
29\end{array}$ & $\begin{array}{r}8.0 \\
14.3 \\
11.6 \\
1.9 \\
20\end{array}$ & $\begin{array}{r}8.0 \\
13.3 \\
11.1 \\
1.6 \\
20\end{array}$ \\
\hline 蛋 & $\begin{array}{l}\min \\
\max \\
\bar{x} \\
\frac{ \pm}{n} \mathrm{SD}\end{array}$ & $\begin{array}{r}3.8 \\
8.0 \\
6.1 \\
1.6 \\
112\end{array}$ & $\begin{array}{l}5.6 \\
8.0 \\
6.5 \\
0.6 \\
77\end{array}$ & $\begin{array}{c}5.7 \\
8.2 \\
6.7 \\
0.7 \\
28\end{array}$ & $\begin{array}{l}5.3 \\
8.2 \\
6.7 \\
0.8 \\
18\end{array}$ & $\begin{array}{c}6.0 \\
8.2 \\
6.8 \\
0.6 \\
19\end{array}$ \\
\hline 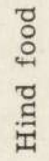 & $\begin{array}{l}\min \\
\max \\
\bar{x} \\
\frac{ \pm}{n} S D\end{array}$ & $\begin{array}{c}11.0 \\
14.9 \\
12.8 \\
1.2 \\
116\end{array}$ & $\begin{array}{c}12.0 \\
15.0 \\
13.2 \\
1.2 \\
84\end{array}$ & $\begin{array}{c}10.5 \\
14.6 \\
13.3 \\
0.9 \\
26\end{array}$ & $\begin{array}{c}12.6 \\
15.0 \\
13.7 \\
0.7 \\
19\end{array}$ & $\begin{array}{c}11.6 \\
14.3 \\
13.2 \\
0.8 \\
12\end{array}$ \\
\hline
\end{tabular}

$100 \%$, the increase in the $7-9$ months old group was $12.4 \%$ or $1.6 \%$ monthly. Later in life the $\mathrm{Cb}$. length was further increasing but the differences between subsequent age groups were not significant. How- 
ever, there was a significant difference between animals $7-9$ months old and animals 25-39 months old. The increase during this period was $3.5 \%$ (Fig. 2). The difference in growth rate between different stages of development was very obvious. The $\mathrm{Cb}$. length increases during the whole life span of the animal but in older age the growth is slow. There were no statistically significant differences between the males and the females with respect to the rate of $\mathrm{Cb}$. length increase or to any of the remaining skull measurements.

$\mathrm{The}$ basal length was increasing very similarly to the $\mathrm{Cb}$. length. The growth curves of these two measurements were almost parallel in all age groups and the period of intensive increase was also until the 8 th month of life (Fig. 2).
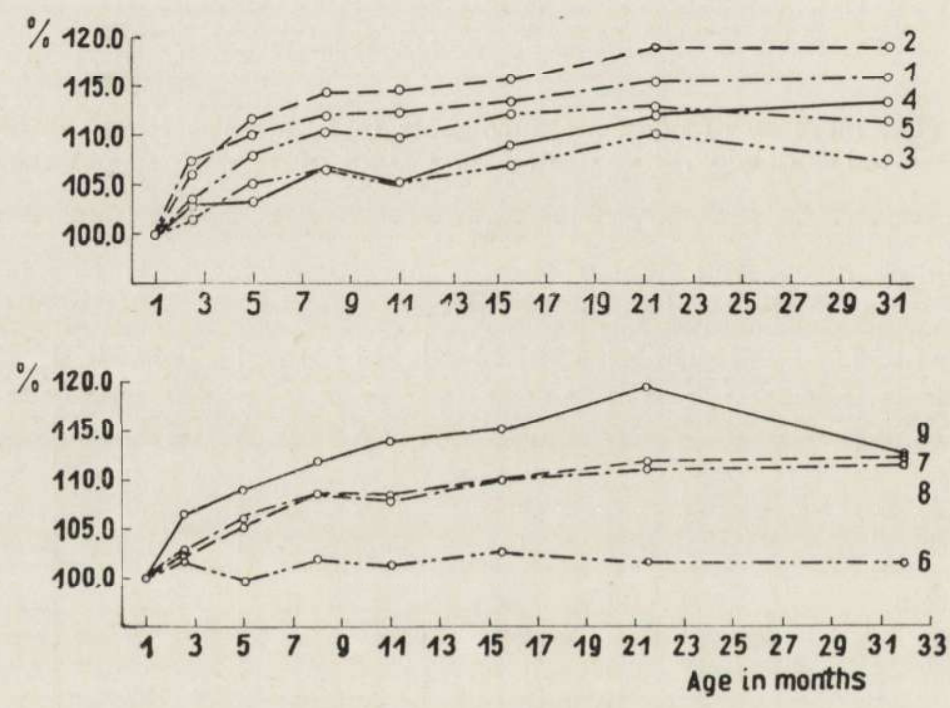

Fig. 2. Per cent increase of skull measurements in L. lagures from the laboratory. 1 - Cb. lenght, 2 - Basal lenght, 3 - Height of skull per bullae tympanici, 4 - Depth of brain case per basi sphenoidale, 5 - Breadth of brain case, 6 Interorbital constriction, 7 - Zygomatic breadth, 8 - Constriction between zygomatic processes of the temporal bones, 9 - Palatal depht.

Height of skull (measured through bullae tympanici) was also increasing until the 8 th month of life. Subsequently it did not change significantly. The mean height of the brain case at one month of age was $6.99 \mathrm{~mm}$, at 8 months $-7.46 \mathrm{~mm}$ (an increase of $6.7 \%$ ) and in the age group 25-39 months $-7.52 \mathrm{~mm}(7.5 \%)$ (Fig. 2).

Depth of the brain case (measured from basi sphenoidale) was increasing intensively during the first 8 months of life. Later the growth rate was much lower and the differences were not significant. 
This dimension in the 1 month old L. lagurus was, on the average, $5.68 \mathrm{~mm}$, at the age of $7--9$ months $-6.07 \mathrm{~mm}$ (an increase of $6.8 \%$ ) and in the oldest group (25-39 months) $-6.44 \mathrm{~mm}$ or $13.4 \%$. Consequently the mean monthly increase beween the age of 7-9 months and $25-39$ months was approximately $0.2 \%$ (Fig. 2).

Breadth of the brain case similarly to the above described measurements, was increasing until the 8 th month and remained stable for the rest of the animals life. However, the 7-9 months old group and the oldest animals differed significantly with respect to both the absolute and the per cent increase.

Zygomatic breadth was increasing intensively also until the animals were 8 months old. Between the age of 1 month and 8 months this measurement increased by $6.2 \%$. In the following months growth was slower and the increase was not significant.

Interorbital constriction reaches its maximum value already in the first month of life and does not change significantly until the end of the animals life. The mean value of this measurement in 1 month old animals was $2.82 \mathrm{~mm}$, while in the $7-9$ months old group and in the oldest animals it was $2.87 \mathrm{~mm}$.

Constriction between the zygomatic processes of the temporal bones. The growth curve of this measure was parallel to that of zygomatic breadth with maximal values at the age of 8 months.

$\mathrm{Palatal}$ depth was increasing also during the first 8 months of life. However, the growth is relatively slow. The mean value at 1 month of age was $4.94 \mathrm{~mm}$ and in the 7-9 months old group $-5.53 \mathrm{~mm}$. The mean monthly increase was $0.06 \mathrm{~mm}$. Later in life the palate does not change significantly its height (5.57 $\mathrm{mm}$ in the oldest age group).

\section{Senile changes in the skull}

The skull of L. lagurus bred in the laboratory for several generations becomes progressively angular with age. On the base of the earlier studies (W a silewski, 1956; Gę bc zyńska, 1964) the skulls were divided into three classes of angularity (Photo 1, 2, 3, Plate XXII):

Class I - skulls without any angularities or additional osseous swells.

Class II - skulls with pronounced thickening of the parietal bone, ossification and thickening of the sutures and well developed angularities on crista nuchalis.

Class III - very obviously angular skulls (Fig. 3).

Class I was most frequent in the age group $1-6$ months. Among the animals 7-12 months old class II was most frequent. In later age this class became more rare and the per cent of class III skulls considerably 
increased (86.4\% among the oldest animals) (Table 3). There was only one exceptional individual in the oldest group which had no angularities on the skull.

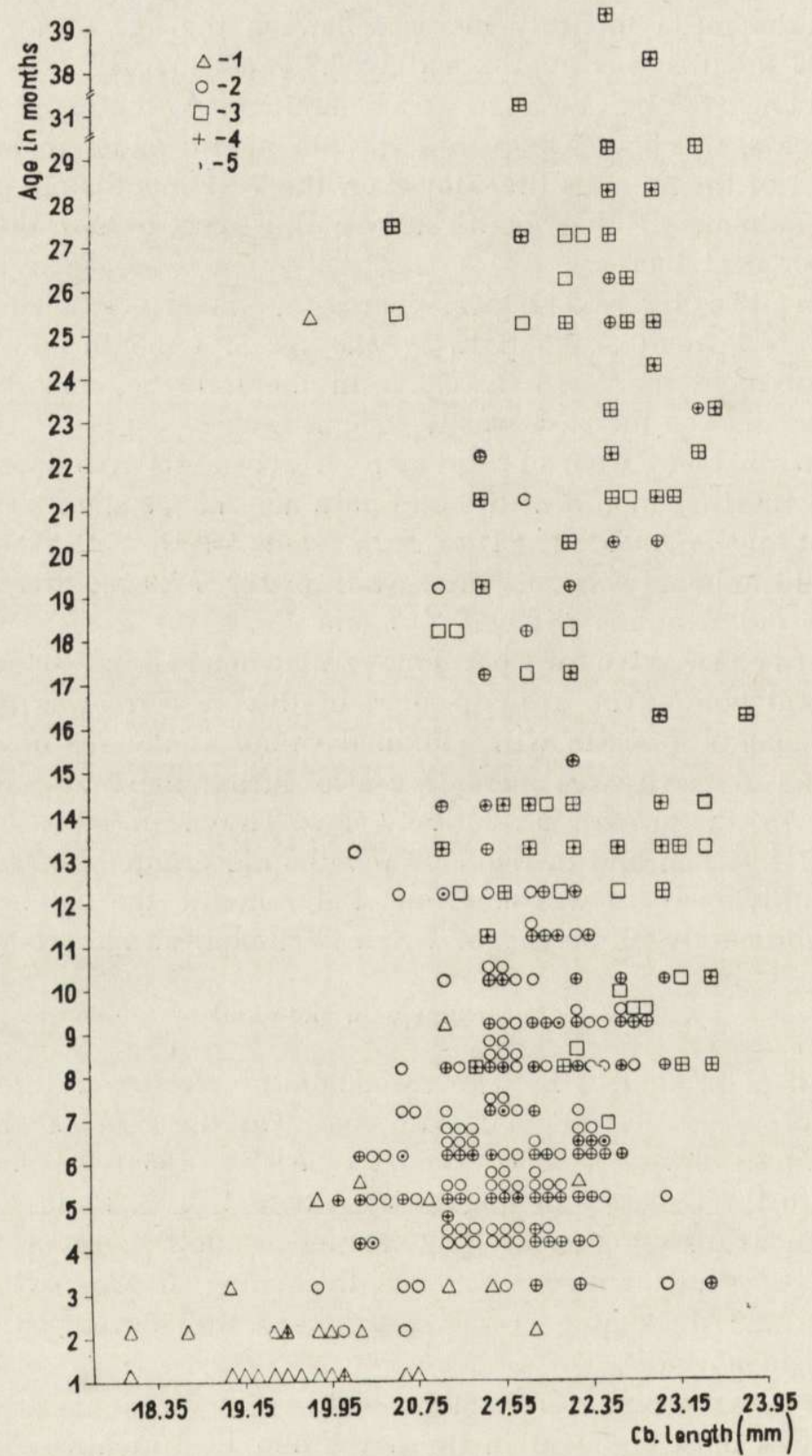

Fig. 3. Development of angularity on the skulls of L. lagurus in the laboratory. 1 - absent, 2 - distinct, 3 - very distinct, 4 - infected with actinomycosis, 5 - tooth anomalies. 
Animals reared in the laboratory quite frequently have a disease of the mandible bones which was identified by Bashenina (1953) as actinomycosis. This disease causes tuberous swellings on the external surface of the mandible bone. The sweels are most frequent in the center of the mandible ramus. Actinomycosis attacks $L$. lagurus already during the first months of life. In the age group $1-6$ months $32.5 \%$ of the animals were infected. This indicates that in the laboratory L. lagurus is more susceptible to actinomycosis than Microtus agrestis. In the latter species actinomycosis never attacked animals less than 8 months old ( $\mathrm{G}$ ę b c z yn ska, 1964). In L. lagurus the highest per cent of actinomycosis infection was observed between 19 and 24 months of age (Table 4).

\section{Table 3.}

The per cent frequency of three classes of angularity in different age group of $L$. lagurus (Explanations in the text).

\begin{tabular}{|c|c|c|c|c|c|}
\hline \multirow{2}{*}{ Class } & - & \multicolumn{5}{|c|}{ Age in months } \\
\hline $1-6$ & $7-12$ & $13-18$ & $16-24$ & $25-39$ \\
\hline I & 25.3 & 12 & - & - & 4.5 \\
\hline II & 73.9 & 79.3 & 25.9 & 36.8 & 9.1 \\
\hline III & 0.8 & 19.5 & 74.1 & 63.2 & 86.4 \\
\hline
\end{tabular}

Table 4.

Number of animals infected with actinomycosis.

\begin{tabular}{|l|c|c|c|c|c|}
\hline Age in months & $1-6$ & $7-12$ & $13-18$ & $19-23$ & $25-39$ \\
\hline Per cent & 32.5 & 41.4 & 70.4 & 84.2 & 72.7 \\
\hline
\end{tabular}

Apart from lesions caused by actinomycosis, animals from our colony quite frequently had teeth damages which resulted from keeping the animals in wire mesh cages. Breaking or notching the incisors brought about numerous deformations of lower or upper teeth rows (overgrowth of molars, bending, complete wearing out). Similar changes were observed in $M$. arvalis ( $\mathrm{M} \circ \mathrm{h} \mathrm{r}, 1950$; A $\mathrm{lth} \mathrm{er}, 1961)$ and in M. agrestis (G ę b c z y ń s k a, 1964).

\section{DISCUSSION}

On the base of four body measurements and eight skull measurements (except the interorbital constriction it can be concluded that $L$. lagurus grows intensively until the 8 th month of life. At this age animals attain their definite size. Only $\mathrm{Cb}$. length and the skull base grow very slowly 
during the rest of the animals life. The interorbital constriction attains its definite dimension already in the first month or life.

Differential growth of skull dimensions causes some lenghtening and considerable flattening of the skull in older animals. Similar flattening of the skull was described in other microtines by Wa silew s ki (1952, 1956, 1960) and Gę bc zyńska (1964).

In the laboratory animals attain their definite size much later than in the field. According to Pol ja k ov $(1950,1951$, cited after Krylzov, 1964) free living animals grow until the 5 th month of life, while $\mathrm{N}$ a umov (1948) reported that they cease to grow already at the age of 3-4 month. According to data of $\mathrm{S} \mathrm{ch} \mathrm{w} \mathrm{a} \mathrm{r} \mathrm{z} \mathrm{et} \mathrm{al.} \mathrm{(1964)} \mathrm{rodents} \mathrm{from} \mathrm{spring}$ generations reach maximal size when $3-4$ months old while in animals from autumn generations the growth stops at the age of 1.5-2 months and is resumed only in spring.

Table 5.

Comparison of some body and skull measurements in L. lagurus from the laboratory and from the field.

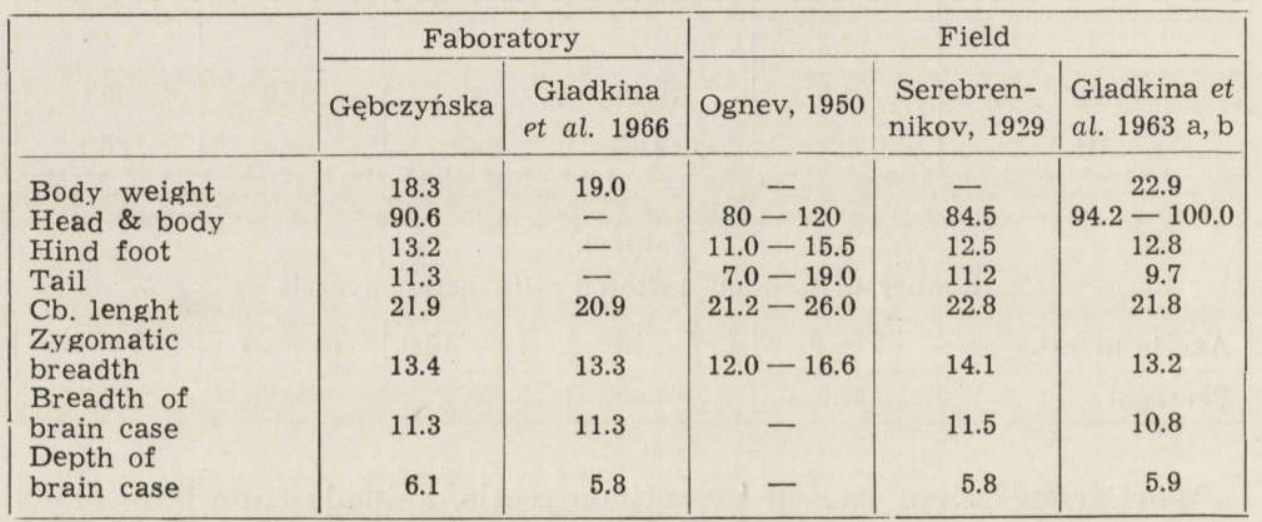

Body weight of laboratory born animals does not depend on their birth date, opposite to the situation in the field where the differences are considerable. The animals from the first litter born in the spring by females which survived the winter grow and gain weight fastest, while subsequent litters grow much slower (K r y l z o w, 1964).

In the laboratory there were no significant differences between the body weight of adult males and adult females (pregnant females were disregarded). However, in the field, adult non-pregnant females are heavier than the adult males (K r y l z ov, 1957).

Some measurements of the body and skull of adult (7-12 months old) $L$. lagurus from the laboratory and from the field were compared using data of Ognev (1950), S e r ebrennikov (1929), Gladkina et al. 
(1963a, 1963b, 1966) and the present work (Table 5). The comparison indicates that the mean body weight of $L$. lagurus from our colony is slightly lower than in other colonies and much lower than in the field. The measurements of the body and the skull are either within the range found in free-living animals or exceed them very slightly (height of the brain case $-0.2 \mathrm{~mm}$ ). This could be due to improper or low-value food or else to the high degree of inbreeding in our colony.

The observation that $L$. lagurus are smaller in the laboratory than in the field is rather interesting as other Microtidae e. g. Pitymys subterraneus, Microtus agrestis or Clethrionomys glareolus reared in the laboratory are much larger than animals of the same age living in the field (W a silewski, 1952, 1960; G ę b c z yńs ka, 1964).

Lagurus lagurus lives much longer in the laboratory than in the field. It is assumed that in natural conditions these animals live from 12 to 18 months (Kryl zov, 1957) and in the laboratory their life span is exended to 39 months.

\section{REFERENCES}

1. A 1 tner H., 1961: Zahnmissbildungen von Wühlmäusen aus Eulengewöllen. Ornithol. Mitt., 13, 10: 181-182.

2. B a shenina N. V., 1953: K voprosu ob opredelenii vozrasta obyknovennoj polevki (Microtus arvalis Pa 11.). Zool. Ž., 32, 4: 730-743. Moskva.

3. G ę bczyńska Z., 1964: Morphological changes occuring in laboratory Microtus agrestis with age. Acta theriol., 9, 6: 67-79.

4. Gę bczyńska Z., 1967: Reproduction of Lagurus lagurus (Pallas, 1773) in the laboratory. Acta theriol., 12, 37: 521-532.

5. Gla dkina T. S., Meyer M. N. \& Mokejeva T. M., 1963a. Vnutrividovaja izmenčivost' stepnoj pestruški i ee prisposobitelnoe značenie. Tr. Vses. nauč.-issled. In-ta zašč. rast., 18: 123-151. Leningrad.

6. Gla dkina T. S., M e yer M. N. \& Mokejeva T. M., 1963b: Vlijanie letnih uslovij na sostojanie stepnoj pestruški i uzkočerepnoj polevki v Severnom Kazahstane. Tr. Vses. nauč.-issled. In-ta zašč. rast., 18: 123-151. Leningrad.

7. Gladkina T. S., M e yer M. N. \& Mokejeva T. M., 1966: Osobennosti razmnoženija i razvitija treh podvidov stepnoj pestruški (Lagurus lagurus) i ih gibridizacija. [In 》Vnutrivid. izmenč. nazemn. pozvonočn. životnyh i mikroévolucija«. Ed. Schwarz. S. S.] Inst. Biol. Ural. Fil. AN SSSR: 203-215. Sverdlovsk.

8. Krylzov A. I., 1957: Izmenenie vesa stepnych pestrušek (Lagurus lagurus P a 11.) v zavisimosti ot ih pola i vozrasta. Zool. Ž., 36, 8: 1239-1250. Moskva.

9. Krylzov A. I., 1964: Stepnye pestruški i stadnye polevki na severe Kazahstana. Tr. nauč.-issled. In-ta zašč. rast., 8: 3-183. Alma-Ata.

10. Mohr E., 1950: Die freilebenden Nagetiere Deutschlands und der Nachbarländer. 1-152+VI. Jena.

11. Na umov N. P., 1948: Očerki sravnitelnoj ékologii myševidnyh gryzunov. Izd. AN SSSR, 1-204. Moskva. 
12. Og n ev S. I., 1950: Zveri SSSR i priležaščih stran., 7: 1-706. AN SSSR. Moskva -Leningrad.

13. Schwarz S. S., Pokrovski A. V., Istchenko V. G., Olenjev V. G., Ovtschinnikova N. A. \& Pjastolova O. A., 1964: Biological peculiarities of seasonal generations of rodents, with special reference to the problem of senescence in mammals. Acta theriol., 8, 2: 11-43.

14. Serebrennikov M. K., 1929: Materialy po sistematike i ékologii gryzunov Južnogo-Zauralja. Ežegodnik Zool. Muzeja. 30, AN SSSR.

15. W a silew ski W., 1952: Morphologische Untersuchungen über Clethrionomys glareolus glareolus (S ch reb.). Annls Univ. M. Curie-Skłodowska, Sect. C, 7, 3: $120-211$. Lublin.

16. W a silewski W., 1956: Untersuchungen über die morphologische Veränderlichkeit der Erdmaus (Microtus agrestis Linné). Annls Univ. M. Curie-Skłodowska, Sect. C., 9, 6: 261-305. Lublin.

17. Wasilewski W., 1960: Angaben zur Biologie der Kurzohrmaus, Pitymys subterraneus (de Sélys - Longchamps, 1835). Acta theriol., 4, 12: 185247.

Received, June 3, 1967.

Polish Academy of Sciences, Mammals Research Institute, Białowieża, Poland.

\section{Zofia GĘBCZYŃSKA}

\section{MORFOLOGICZNA ZMIENNOSĆ LAGURUS LAGURUS (P A L L A S, 1773) W WARUNKACH LABORATORYJNYCH}

\section{Streszczenie}

Od 1961 roku prowadzona jest w Zakładzie Badania Ssaków PAN w Białowieży hodowla L. lagurus (,leming stepowy”), której celem jest przystosowanie tego gatunku do warunków laboratoryjnych. Jednym z opracowywanych zagadnień było prześledzenie zmian zachodzących $\mathrm{w}$ rozwoju pozagniazdowym $\mathrm{w}$ ciężarze i wymiarach ciała oraz w wymiarach i wyglądzie czaszki.

Przebadano 281 osobników, w tym 136 samic i 145 samców w wieku od 1 do 39 miesięcy (Tabela 1). Czaszki wykorzystane do pomiarów utrwalone były w alkoholu. Istotność różnic poszczególnych pomiarów sprawdzono testem $t$ Studenta, dla dwóch grup niezależnych oraz testem Tuckey'a.

Stwierdzono, że długość ciała, ogona, stopy i ucha oraz wszystkie wymiary czaszki (z wyjątkiem szorokości międzyoczodołowej) rosną intensywnie do 8 miesięcy życia (Ryc. 1, 2a, 2b,). Do końca życia rośnie długość Cb. i podstawa czaszki. Szerokość międzyoczodołowa osiąga osiąga swój ostateczny wymiar w 1 miesiącu życia. Nie stwierdzono statystycznie istotnych różnic między samcami i samicami.

Ciężar zwierząt hodowlanych ulega wahaniom w ciągu ich życia. Maksimum osiąga w wieku około 1 roku (17.8 g) i nie różni się istotnie u samców i samic (samice kotne wyłączono $\mathrm{z}$ obliczeń) we wszystkich klasach wiekowych. 
W miarę starzenia się zwierzęcia czaszka staje się coraz bardziej kanciasta. Opierając się na różnym stopniu wykształcenia tych kanciastości, podzielono opracowywany materiał na 3 klasy. W klasie I zgrupowano czaszki nie posiadające żadnych kanciastości ani dodatkowych zgrubień. Osobniki o takich czaszkach występują najliczniej w grupie wiekowej $1-6$ miesięcy. Do klasy II zaliczono te osobniki, u których następuje widoczne grubienie kości ciemieniowej, kostnienie i grubienie szwów oraz występują wyraźnie rozwinięte kanciatowości na grzebieniu karkowym. Klasa ta najliczniej reprezentowana jest wśród zwierząt 7-12 miesięcznych. Klasa III objęła czaszki bardzo wyraźnie kanciaste. Należą do niej osobniki najstarsze (Tabela 3 ).

Stosunkowo często u L. lagurus trzymanego w laboratorium spotyka się schorzenia kości żuchwy, określone jako aktinomykoza. W grupie zwierząt $1-6$ miesięcznych $32,5 \%$ osobników jest zarażonych, a 19-24 miesięcznych aż $84, \%$ (Tabela 4).

Na podstawie zestawienia danych różnych autorów stwierdzono, że L. lagurus w hodowli ma rozmiary mniejsze niż w terenie (Tabela 5). Jest to zjawisko ciekawe, gdyż inne Microtidae w warunkach hodowlanych osiągają wymiary znacznie większe, niż zwierzęta $\mathrm{w}$ tym samym wieku w terenie.

Długość życia osobników laboratoryjnych dochodzi do 39 miesięcy i przewyższa maksymalny wiek $\mathrm{w}$ terenie (18 miesięcy).

\section{EXPLANATION OF PLATE XXII}

Development of angularity on the skulls of L. lagurus. Photo 1 - class I, Photo 2 - class II, Photo 3 - class III, Photo 4 - mandible infected with actinomycosis. 


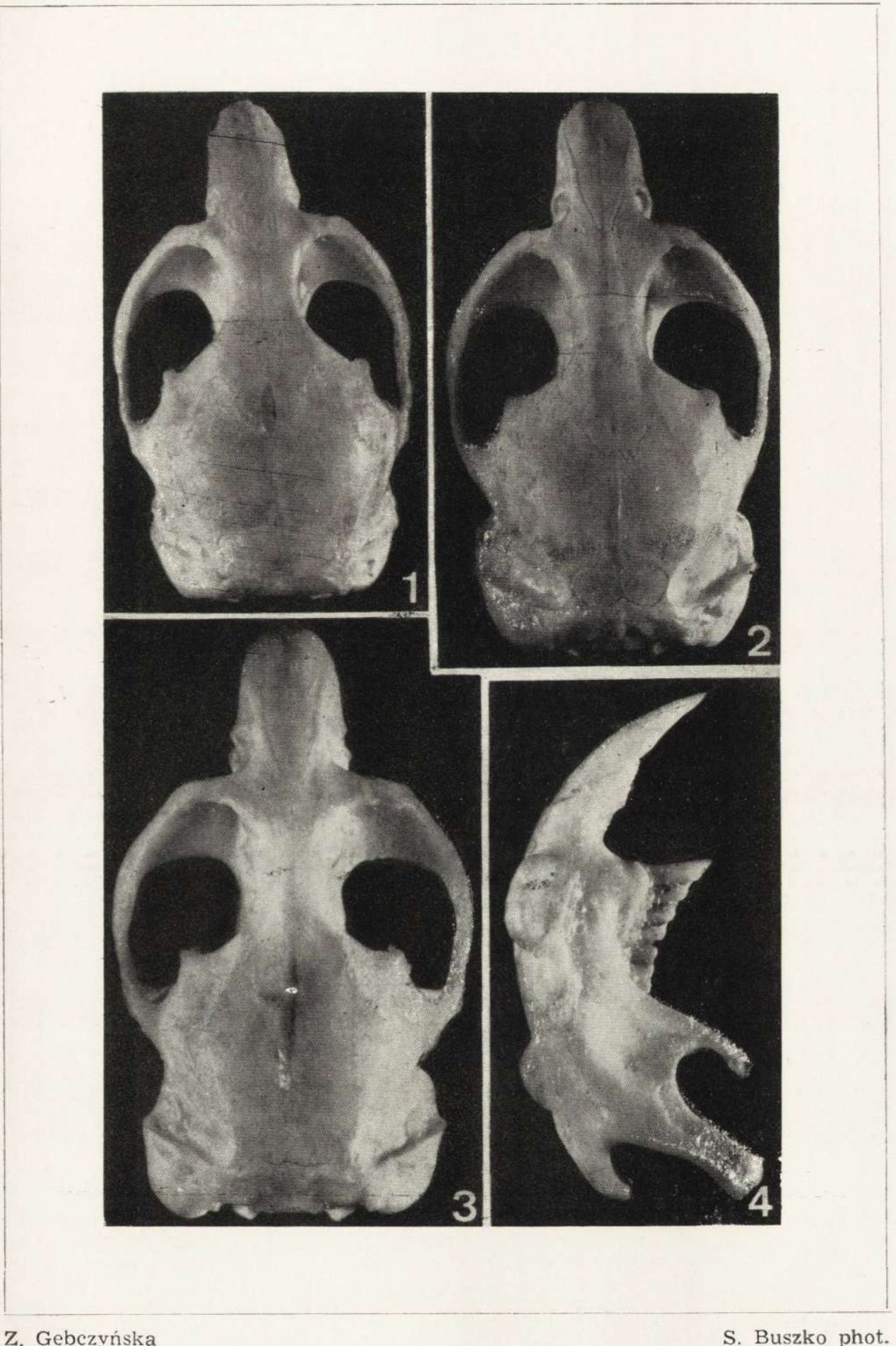

